\title{
Interim Guidance for Zika Virus Testing of Urine — United States, 2016
}

On May 10, 2016, this report was posted as an MMWR Early Release on the MMWR website (http://www.cdc.gov/mmwr).

Diagnostic testing for Zika virus infection can be accomplished using molecular and serologic methods. Real-time reverse transcription-polymerase chain reaction (rRT-PCR) is the preferred test for Zika virus infection because it can be performed rapidly and is highly specific $(1,2)$. However, in most patients, Zika virus RNA is unlikely to be detected in serum after the first week of illness $(2,3)$. Recent reports using adaptations of previously published methods $(2,4)$ suggest that Zika virus RNA can be detected in urine for at least 2 weeks after onset of symptoms (3,5-7). Currently, the CDC Trioplex rRT-PCR assay is the only diagnostic tool authorized by the Food and Drug Administration for Zika virus testing of urine (1). Other laboratory-developed tests will need in-house validations to adequately characterize the performance of the assay and meet Clinical Laboratory Improvement Amendments requirements. Further investigation is needed to determine the sensitivity and utility of Zika virus rRT-PCR on urine specimens collected $\geq 14$ days after onset of symptoms.

On the basis of the newly available data, CDC recommends that Zika virus rRT-PCR be performed on urine collected $<14$ days after onset of symptoms in patients with suspected Zika virus disease. Zika virus rRT-PCR testing of urine should be performed in conjunction with serum testing if using specimens collected $<7$ days after symptom onset (8). A positive result in either specimen type provides evidence of Zika virus infection. Procedures for the collection and submission of body fluids, including urine specimens, have been described previously (9). CDC recommendations for Zika virus testing of serum and other clinical specimens remain unchanged at this time (8). CDC will continue to review and update guidance for Zika virus testing as new data become available.

\section{References}

1. Food and Drug Administration. Zika virus emergency use authorization. Silver Spring, MD: US Department of Health and Human Services, Food and Drug Administration; 2016. http://www.fda.gov/MedicalDevices/ Safety/EmergencySituations/ucm 161496.htm

2. Lanciotti RS, Kosoy OL, Laven JJ, et al. Genetic and serologic properties of Zika virus associated with an epidemic, Yap State, Micronesia, 2007. Emerg Infect Dis 2008;14:1232-9. http://dx.doi.org/10.3201/ eid1408.080287

3. Bingham AM, Cone M, Mock V, et al. Comparison of Zika virus testing in serum, urine and saliva specimens from travel-associated Zika virus disease cases_Florida, 2016. MMWR Morb Mortal Wkly Rep 2016;65(18). Epub May 10, 2016.

4. Wæhre T, Maagard A, Tappe D, Cadar D, Schmidt-Chanasit J. Zika virus infection after travel to Tahiti, December 2013. Emerg Infect Dis 2014;20:1412-4. http://dx.doi.org/10.3201/eid2008.140302

5. de M Campos R, Cirne-Santos C, Meira GL, et al. Prolonged detection of Zika virus RNA in urine samples during the ongoing Zika virus epidemic in Brazil. J Clin Virol 2016;77:69-70. http://dx.doi. org/10.1016/j.jcv.2016.02.009

6. Rozé B, Najioullah F, Fergé JL, et al.; GBS Zika Working Group. Zika virus detection in urine from patients with Guillain-Barré syndrome on Martinique, January 2016. Euro Surveill 2016;21:30154. http://dx.doi. org/10.2807/1560-7917.ES.2016.21.9.30154

7. Gourinat AC, O’Connor O, Calvez E, Goarant C, Dupont-Rouzeyrol M. Detection of Zika virus in urine. Emerg Infect Dis 2015;21:84-6. http://dx.doi.org/10.3201/eid2101.140894

8. CDC. Memorandum: revised diagnostic testing for Zika, chikungunya, and dengue viruses in US public health laboratories. Atlanta, GA: US Department of Health and Human Services, CDC; 2016. http://www. cdc.gov/zika/pdfs/denvchikvzikv-testing-algorithm.pdf

9. CDC. Collection and submission of body fluids for Zika virus testing. Atlanta, GA: US Department of Health and Human Services, CDC; 2016. http://www.cdc.gov/zika/hc-providers/body-fluids-collectionsubmission.html 